\begin{tabular}{|c|c|}
\hline Title & The contest for leadership in East A sia : Japanese and Chinese approaches to outer space \\
\hline Author(s) & Suzuki, Kazuto \\
\hline Citation & $\begin{array}{l}\text { Space Policy, 29(2), 99-106 } \\
\text { https://doi.org/10.1016/.spacepol.2013.03.006 }\end{array}$ \\
\hline Issue Date & $2013-05$ \\
\hline Doc URL & http:/hdl.handle.net/2115/53073 \\
\hline Type & article (author version) \\
\hline File Information & 2012 Space Policy article revised-Clear-HUSCA P.pdf \\
\hline
\end{tabular}

Instructions for use 


\title{
The Contest for Leadership in East Asia: Japanese and Chinese Approaches to Outer Space
}

Kazuto Suzuki

Hokkaido University / Princeton University

\begin{abstract}
$\underline{\text { Abstract }}$
Japan and China, two advanced spacefaring nations in Asia-Pacific region, often referred as rivals in space. China's successful manned space launch program in 2003 and ASAT test in 2007 were considered as turning points, which potentially introduce "space race in Asia". This article defines that there are three facets of space race, competition of prestige or soft power, competition of military capability or hard power, and competition of international services or public goods. It analyzes the objectives, norms and logics of space policy in Japan and China, and argues that these two countries have quite different thinking over what to do in space, and explains that they are playing different games in the first two facets. However, Japan and China are competing for leadership and influence over the region. APRSAF and APSCO, two similar regional space organizations, are the vehicles for this competition. It concludes that there is a space race only on the third facet as a competition of the leadership in Asia.
\end{abstract}

$\underline{\text { Introduction }}$

In Asia, it has been said that there is a space race among Japan and China [1][2][3]. Two countries launched satellites of their own for exploring the Moon in 2007. The proximity of the function and nature of these two probes gave impression that two countries seemed as if they were competing against one another to be the first country in Asia to reach the Moon. Also, because of the success of Chinese manned space program, it seemed that China is aiming to establish superior position in the space community of the world, and it is anticipated that Japan will develop autonomous manned space capability and compete with China [4]. It is also regarded that the competition of sending probes to the Moon would extend to much wider competition, even a military one, among Asian countries as it did in the time of Cold War [5]. Particularly when Japan revised its space policy by establishing the Basic Space Law in 2008, which altered the interpretation of the concept of "Exclusively Peaceful Purpose" and allowed Japanese space activities for undertaking activities "to ensure international peace and security and also to contribute to our nation's security”, there were many scholars and commentators made predictions that Japan will be more aggressively investing in military space activities [6]. In short, there was a general understanding, or even fear, that the 
space power has shifted to the East, and the competition among Asian countries would result much higher tension and friction among them.

However, this perspective is very much influenced by the Cold War image, and it might be misleading to employ the Cold War analogy. Both Japan and China have their own reasons and logics for sending Moon probe, which may not be associated with the ambition for competing one against another. The task of this article is to examine whether the Cold War analogy of space race is really happening in Asia between Japan and China.

Although there are other countries which are interested in developing space capability in Asia, Japan and China are the two most influential countries in this region. One can argue that India can also be a part of the Asian space race, if any, but this article assumes that Indian space policy, which has strong focus on developing space infrastructure for domestic purposes [7], is still less ambitious to exercise its influence in the region. While Japan and China are taking the leadership for regional organizations, India has not established such position in the region yet (though Indian space agency, Indian Space Research Organization (ISRO), has established Center for Space Science and Technology Education in Asia and the Pacific with sponsorship with the United Nations). Although the number of operational satellites of India exceeds that of Japan, most of Indian satellites are used for domestic socio-economic purposes (Figure-1). In terms of the size of civilian space budget, Japan spent \$3.84 billion and China did \$3.08 billion, India spent only \$1.44 billion in 2011 [8]. Recently, India has increased its interest on the issues of space security and expressing its position on this issue. However, the argument about space security is subjected more global than regional concerns [9], whereas Japan, together with Australia, is trying to organize a regional framework for involving Asian countries in the debate over space security through Asia-Pacific Regional Space Agency Forum (APRSAF) and ASEAN Regional Forum (ARF). Thus, this article will focus on the objectives, rationales and exercises of influence of Japan and China as space power, and examines whether the competition of the influence or leadership can be understood as "space race”.

Figure-1 Number of Operational Satellite in Major Asian Spacefaring Countries

\begin{tabular}{|l|l|l|l|l|l|l|l|l|l|}
\hline & Commercial & \multicolumn{4}{l|}{ Civil/Government } & \multicolumn{2}{l|}{ Military } & Total \\
\hline & Com & Com & EO & Nav & RS & Met & Recon & Nav & \\
\hline China & & 23 & 6 & & 11 & 2 & 12 & 15 & 69 \\
\hline India & & 11 & 11 & & & & 3 & & 25 \\
\hline Japan & 17 & & 3 & 1 & & 2 & $* 5$ & & 23 \\
\hline
\end{tabular}




\begin{tabular}{|l|l|l|l|l|l|l|l|l|l|}
\hline S.Korea & 2 & & 3 & & & & & & 5 \\
\hline
\end{tabular}

* Japanese IGS is operated by civilian intelligence agency

Source: Satellite Database; UCS 2011

\section{What is Space Race?}

Space race during the Cold War was defined as an informal competition between the United States and Soviet Union for achieving in the field of space exploration [10], which includes manned and unmanned programs. The main driving force of the competition in space exploration was largely the demonstration of technical capability and international prestige. The race to the Moon or the race of duration of manned space flight was regarded as another form of non-military competition of national prestige such as Olympic game. In other words, the space race during the Cold War was mainly competition in civilian space activities.

However, the US-Soviet space race was not limited to the competition in civilian space exploration. Both United States and Soviet Union competed in developing technological capability to improve their military might. Not only the development of launcher technology for the improvement of missile technology, but also various space capabilities including telecommunications, Earth observation, navigation and meteorology were all related to the improvement of their military capability. This competition of military space capability was not covered as wide as competition in space exploration, but there certainly was a competition.

Also, the space race was not only about the competition of technological capability. It was also about the provision of services. The Soviet Union has created Intersputnik for providing satellite telecommunications and Intercosmos for providing scientific and manned exploration opportunities for friendly countries. Although it was not completed before the Soviet Union collapsed, it developed GLONASS satellite navigation capability. These were in Cold War competition with American space-based services. The United States led the creation of Intelsat for telecommunications, GPS for navigation, and International Space Station Freedom for manned space flight opportunities for its allies.

From these account, it can be said that there are three different facets of space race. The first is the competition of prestige or soft power, the second is the competition of military capability or hard power, and the third is the competition of international services or public goods. If there is a space race between Japan and China, which facet are they competing? 
In order to analyze on which facet Japan and China are competing, this article scrutinizes the historical development of their space activities and tries to find out the objectives and intentions of their space activities. It will allow us to understand why they are competing in one facet and not in the other. The space race is supposed to have both players on the same game. If one country invests heavily on the manned space flight for achieving international prestige but other country doesn't, it is not a race. Thus, this article will seek the facet where both countries are involved in.

\section{$\underline{\text { Japan }}$}

\section{Origin of Japanese space policy}

Since the beginning of space activities, Japan has been shy from engaging in any military-related use of space. It is largely due to the fact that Japan, with a pacifist Constitution, refrained from using space for security purposes. Although the 2008 Basic Space Law introduced the concept of using space for "international peace and security" and contributing "to our nation's security", there are only limited engagement by the Ministry of Defense (formerly Japanese Defense Agency: JDA) and Self-Defense Forces (SDF) in space up until today.

The hesitance in military-related space investment and utilization was not only defined by its constitution but also historically developed institutions around space activities. In 1969, the Diet has adopted a resolution called "Space Development for Exclusively Peaceful Purposes", which set a limit for Japanese government that any involvement of defence authority for investing in, owning of, and operating space systems. In other words, all Japanese space programs should be excluded any military element, and conducted under civilian authority in the name of research and development of new technology [11].

Although the term "Exclusively Peaceful Purposes" is not unique (as it appears in Treaty of Outer Space or ESA Convention), the interpretation of this clause in Japan is quite unique. In the deliberation of the resolution in 1969, the Diet members argued that this clause should be interpreted as in the case of peaceful use of atomic energy. For Japanese minds, both atomic energy and space are dual-use technology, i.e. technology which can be used both civil and military purposes, and both are developed for military purposes. Since Japan has been suffering from the trauma of nuclear holocaust in Hiroshima and Nagasaki, there was a very strong scepticismbo towards the peaceful use of nuclear technology. Although Japan had already started developing its own launching capability led by Professor Hideo Itokawa using solid propellant technology, Japanese government and public 
did not concern the possible conversion of such technology into military purpose. However, when the United States decided to transfer the out-of-date liquid propellant launcher (Thor-Delta) to Japan, the opposition parties, particularly the Socialist Party, expressed the concern that the American launcher technology was derived from military program, and acceptance of such technology would suggest the government's ambition for developing launching capability [12]. As a result, the Diet put clear distinction that the technology should only be used civilian purposes, which means that defence authority should not administratively, financially and politically involved in the development and operation of space technology programs [13]. In other words, the "Exclusively Peaceful Purpose" was interpreted that space technology should not only be used for aggressive actions ("non-aggressive”) but also prohibited from any military authority to develop, own, operate and use ("non-military").

\section{Shocks in Post-Cold War Period}

For a long time, particularly during the Cold War, the "non-military" nature of space did not encounter any problem. The US-Japan alliance provided necessary infrastructure for intelligence gathering and telecommunication from space, and the pacifist Constitution prohibited Japanese SDF to be deployed beyond Japan's border.

However, the perception of Japanese people on security matters has dramatically changed by two events. First, the imminent threat of North Korea became visible when the Taepodong, satellite launcher/ballistic missile, flew over Japanese territory in 1998. It was a huge shock on the pacifist policy paradigm. This incident put Japanese public as well as policy community in a panic mode. There was a strong demand to do something for avoiding North Korean to launch missiles towards Japan and protect its homeland. Thus, immediately after the Taepodong launch, the government made a decision to start a new satellite program, Information Gathering Satellite (IGS).

The launch of IGS faced serious constraints of the existing legal interpretation. Although it was clear that the purpose of IGS was to monitor military activities of possible threats such as North Korea, but it was administratively defined as a "crisis-management" (note: it was even difficult to mention "dual-use" because it implies the possibility of the participation of JDA) satellite, which also serves for civilian purpose in order to comply with the 1969 Resolution. The Cabinet Intelligence and Research Office under the Prime Minister's Office, instead of JDA, was designated as the operator of IGS [14]. The process of decision-making proved to politicians that the legal constraints of "Exclusively Peaceful Purpose" resolution was too strict to have a room for manoeuvre, and under the changing security environment in the post-Cold War period, it seems 
non-sense to maintain such a rigid pacifist rule. However, since there was no time and momentum for changing the definition of the "Exclusively Peaceful Purpose", the politicians used acrobatic skill to place IGS within the Prime Minister's Office where there was no competence for interpretation of satellite imagery.

\section{Basic Law for Space Activities}

Politicians of ruling LDP launched a study group on legal and political issues of Japanese space activities in 2005 and identified the problems of bureaucratically driven space policy. This study group issued a report in 2006 and urged LDP to propose new legislature for regulating space activities by creating a ministerial post with a portfolio of space, establishing a new government forum for space user ministries, and changing the interpretation of 1969 Diet resolution [15]. This report was well accepted by the politicians not only within LDP but also its coalition partner, Komeito, and largest opposition party, Democratic Party of Japan (DPJ). These three parties submitted a draft bill of Basic Space Law and it passed the Diet by July 2008.

The Basic Space Law defines the direction of new space policy and new decision-making structure. First, it will set up new Minister for Space and Space Development Strategy Headquarters (a Cabinet-level decision-making body). The Minister for Space would be a "specially designated" minister who will not be in charge of the management of the ministry but to reside in the Cabinet Office for coordinating policies of different ministries. The Headquarters are composed of all the ministers including the Minister of Defense. The Headquarters is the final decision-making body for the allocation of budget by bundling all budget requests from various ministries. Following the establishment of the Basic Space Law in 2008, the Diet passed another law to reorganize the administrative body in 2012. The main purpose of this law was to establish the Office for Space Strategy under the Cabinet Office, which directly reports to the Chief Secretary of the Cabinet (government spokesperson and the right hand person to the Prime Minister). The creation of new office in the Cabinet Office means that the center of space decision-making will be transferred from the Ministry of Education, Culture, Sports, Science and Technology (formerly Science and Technology Agency: STA). The purpose of this transfer is that the Japanese space activities will focus more on the strategic aspect rather than the science and technology issue.

The second feature of the Law pertains to security. Article 2 of the Law states that "Our space development shall observe the Outer Space Treaty and other international agreements and shall be conducted in accordance with the principle of pacifism upheld in the Constitution." In other words, the traditional interpretation of "Exclusively Peaceful Purposes" as "non-military" should no longer 
apply. Instead, the policy should be to adopt the international standard interpretation of the "peaceful use" of space as the "non-aggressive" use of space. The new Law would accordingly enable the Japanese defense authority to be involved in the development, procurement, and operation of space systems.

In addition, Article 3 states that "the government shall take necessary measures to promote space development that will contribute to international peace and security and also to our nation's security." Because this statement is so general, Article 3 could be interpreted as allowing the government to use space systems for aggressive purposes. But because Article 2 stipulates that the use of space systems for national and international security comply with both the framework of international agreements and Japan's Constitution, it implies that Japan may use its space assets for crisis management and disaster monitoring in Asia and for peacekeeping missions outside its territory. Article 2 also suggests that Japan can use early warning satellites for its missile defense, as this falls into the category of self-defense [16].

Responding the establishment of the Basic Space Law, the MoD has created the "Office of Space and Maritime Policy” as an administrative body dedicated to space and maritime security in 2008. However, the office has very limited capability with small number of staff allocated to space. The executives of the $\mathrm{MoD}$ were not very enthusiastic to invest in space for several reasons. First, under heavy budgetary constraints, Defense budget was targeted as the source of spending cuts. In order to protect existing programs, there was no luxury to increase spending for unfamiliar domain of space. Second, due to the long period of refraining from the investment in space, MoD has almost no staff or technical expertise in space technology that eventually make MoD to depend on JAXA. Given the secretive nature of $\mathrm{MoD}$, it would not be acceptable to depend on civilian agency to develop military sensitive technology. So, instead of cooperating with JAXA, MoD chose not to invest much in space. For these reasons, the role of $\mathrm{MoD}$ was limited even after the establishment of the Basic Space Law.

The Basic Space Law, therefore, is designed to strengthen Japan's capability in settling disputes and managing crises by peaceful means and is intended to change only the interpretation of the Diet resolution, preventing any use of space by Japan's military authority. In other words, the statements made by experts on Japan, such as Bill Emott [17], Pekkanen [18], and Pekkanen and Kallender-Umezu [6], that Japan will soon become military space power are very misleading, if not wrong.

\section{Is Japan going to be a big space power in the next decade?}


One of the motivations for LDP politicians to promote the Basic Space Law was to strengthen Japan's capability for using space in international affairs, because they were very concerned about the development of the Chinese space program. Of course, the members were impressed by the successful manned-space program, but their concern was not about the competition in the manned-space capability nor in the space race for the Moon. Mr. Kawamura, who was the leading figure of the movement for establishing the Basic Space Law and became Chief Secretary of the Cabinet in 2008, congratulated China for the third successful manned space mission and the first Extra-vehicular Activity (EVA) without hesitation. He praised that the Chinese manned space flight was good for the humanity and stated, in response to the question, that there is no Japanese autonomous manned space program in sight [19].

Instead, their attention was paid to the recent development of Chinese action towards other Asian countries. In 2005, the Chinese government concluded the signing of the establishing agreement for APSCO (Asia-Pacific Space Cooperation Organization). Prior to APSCO, AP-MCSTA (Asia-Pacific Multilateral Cooperation in Space Technology and Applications) was already established in 1992 with 13 member states. AP-MCSTA was an organization for technical cooperation framework with particular focus on developing small satellite technology and user-oriented applications, and APSCO inherited this organization with stronger legal framework (see next section for detail). Both APSCO and AP-MCSTA were initiated by the Chinese government, and they are attracting a lot of attention from developing countries. For many years, Japan was the leading country in this region and JAXA and MEXT were proud to initiate APRSAF (Asia-Pacific Regional Space Agency Forum), established in 1993, which coordinates the space program and enhance the cooperation among the space agencies in this region. However, this organization, as one might imagine, focused only on technical and educational aspects of the space cooperationprogram only among different space agencies. There was a deep dissatisfaction among the LDP politicians that Japan was not supporting the needs of developing countries, which was the transfer of technology and collaborative projects for space hardware, as APSCO does.

In response to these demands and fear of losing leadership in Asian region, JAXA has initiated several projects to go beyond the "talking among space agencies". In 2005 at APRSAF meeting in Fukuoka, JAXA has proposed Sentinel-Asia program. This was inspired by the EU-ESA-sponsored GMES (Global Monitoring for Environment and Security) program to provide regional imagery data for environment and disaster management [20]. It uses Japanese Earth observation satellite "Daichi (ALOS)" and NASA's MODIS as well as software and network called Digital Asia that was developed by Keio University of Japan. Furthermore, JAXA initiated SAFE 
(Space Application For Environment) program to analyze climate change by monitoring water resources, sea level, forest degradation, and agricultural data.

However, these programs were not enough to satisfy other Asian partners because they demanded further technology transfer. Thus, in 2009, JAXA initiated STAR (Satellite Technology for the Asia-Pacific Region) program which mimicked APSCO’s Small Multi-Mission Satellites (SMMS). The STAR program includes Malaysia, Thailand, India, South Korea, Indonesia and Vietnam for developing small satellites (Micro-STAR and EO-STAR) together with JAXA. This was a big step ahead for APRSAF to become more technology-oriented forum, but the commitment of JAXA for this program seems to be ambivalent. Because of security concerns, JAXA is not free to transfer all necessary technologies for developing small satellites under various legal frameworks on export control and the "Exclusively Peaceful Purpose" clause in the Law to Establish JAXA. Although Basic Space Law allows JAXA to perform intensive international cooperation, but other related laws are not sufficient to provide enough room for JAXA to commit on these programs [21]. This was the reason for the Diet to pass additional legislation to modify the Law to Establish JAXA in 2012.

Furthermore, the role of the Ministry of Foreign Affairs (MoFA) has changed after the establishment of the Basic Space Law. The MoFA has created the "Office of Space" under the Foreign Policy Bureau, and assigned several diplomats to dedicate their efforts to utilize space systems and activities for the diplomatic affairs. In fact, MoFA supported the first ARF Space Security Workshop in Hoi An, Vietnam and sponsored a session on space security at APRSAF-19 in Kuala Lumpur in 2012.

In addition to the multilateral engagement, MoFA, JAXA and Japanese space industry collaborate to penetrate into growing Asian space market through bilateral relationship. In 2011, Japanese government provided about 1 billion US dollar-worth Official Development Assistance (ODA) to Vietnam to support procuring Japanese Earth observation satellites (ASNARO). This was not only the commercial contract to sell Japanese satellites, but also support increasing ground infrastructure and developing human resources for imagery analysis in Vietnam. These activities are based on the new concept of "space diplomacy", which means that using Japanese space capability to support Japanese diplomatic activities. The concept of "space diplomacy" was embedded in the Article 6 of the Basic Space Law, which says "Space development and utilization shall contribute to improve our role in the international society and to increase our national interest by promoting international cooperation and diplomacy on space development and utilization”.

MoFA argued that increasing number of countries in Asia-Pacific region began using space systems 
as their national infrastructure, which provides indispensable services to their socio-economic activities. Japan as one of the leading spacefaring nations in this region is taking a leading role to formulate regional space cooperation framework which includes a forum to discuss space security [22].

\section{Japanese approach to 'space race' in Asia}

In sum, Japanese space policy has changed dramatically in recent years, and it seems that the direction of the policy seems to change towards strengthening space capability for security and diplomacy. However, as it is discussed, the introduction of IGS was a response to the North Korean missile launch in 1998 and to improve intelligence capability rather than using it for aggressive purpose. The changes of the interpretation of "Exclusively Peaceful Purpose" allows military authority to invest, develop, own and operate space systems, but the change is still limited under the constraints of the pacifism in the Constitution, which does not allow the government to use military force to solve international crisis. Instead, the newly emerging policy direction was to use space system for diplomacy and international leadership. As it is discussed, this objective has been supported by politicians whose interest in using space as a "tool" for providing benefits to other countries, especially developing countries. They believe that providing security-related services such as disaster monitoring and confidence building measures would improve the role and status of Japan in the region and international arena. Meanwhile, politicians are concerned the cost and benefit of space activities, and it would be difficult to promote "big projects" such as manned-space programs.

From the perspective of this article, this analysis invites a Japanese view on space race in Asia. For the first facet, competition of prestige or soft power, Japan is not trying to challenge Chinese effort for manned space flights or other glorious space programs. Instead, it is focusing on less attractive but more practical use of space. For the second facet, competition of military capability or hard power, the launch of IGS and the Basic Space Law seem to give Japan the opportunity to improve its military capability, but the Article 2 of the Basic Space Law prevents the government to use space for aggressive purposes and to strictly remain on the "spirit of pacifism of the Constitution". Although the tension between Japan and China over Senkaku/Diaoyu Islands is rising, the MoD is still not willing to invest in space capability. Even when the existing contract for satellite communication capability with commercial company, Sky Perfect JSAT, is about to expire, the MoD decided not to develop its own military communication satellite, but to contract with Sky Perfect JSAT to provide satellite capability in the form of Private Finance Initiative (PFI). Thus, from Japanese perspective, the space race against China happens only in the third facet, competition of 
international services or public goods. Through APRSAF, Japan provides satellite services for disaster management, environmental protection or improving productivity in agriculture. Also, through initiatives such as STAR program and financial incentives by official development assistance (ODA) for purchasing Japanese satellite systems, Japan is trying to use its advanced space technology for the regional leadership.

\section{China}

Chinese space activities are opaque at best. Even in decision-making process of military and civilian programs, it is not clear which agencies and companies are involved in the program. When it comes to the military programs, it is almost impossible to penetrate into decision-making community. Because of this opaqueness, there are many analysis of Chinese space policy with a lot of guessing games and speculations. However, it is possible for us to understand the general trend of Chinese space program and its normative understanding on how space should be used.

\section{Sleeping Dragon is Waking Up}

The emergence of China as a space power is widely recognized in 2000 when Chinese State Council issued the first White Paper on Space Activities [23]. This White Paper was the first public statement on what China aims and achieved in space. It emphasizes on the one hand, utilization of space for peaceful purposes and promotion of the benefit to all mankind, but on the other hand, protection of China's national interests and strength and implementation of national development strategy.

This dichotomy of global/national ambivalence can be seen in many parts of Chinese strategy for space. On the one hand, China National Space Agency (CNSA) and China Aerospace Science and Technology Corporation (CASTC), both established in 1993, are institutionally under Committee on Science and Technology Industry for National Defence (COSTIND). These two major organizations are strongly influenced by national political climate and strategic objectives, but they are relatively autonomous from defence community, and there is a little communication and exchange of information between defence authority and CNSA. This relative autonomy from military came from the historical background. During the Cultural Revolution in the late 1960s to early 1970s, the Prime Minister Zhou Enlai has moved space scientists and engineers to the military in order to protect them from the hunt of intellectuals [24]. But on the other hand, China Academy of Sciences (CAS) and various technological institutions are generally autonomous from national political objectives and tend to emphasize the importance of Chinese contribution to humanity [25]. 
The remarkable point in this White Paper is the emphasis on application programs. China has not invested extensively on application technology for a long time. Instead, Chinese government sought to acquire application satellites from foreign manufacturers. However, the US export control restriction, known as ITAR (International Traffic in Arms Regulation), put satellite and space technology as a controlled items under Munitions List. This meant that export of US-made satellite as well as satellite made with any components and parts produced in the US needs to be approved by the Department of State. Because of the competitiveness of the US space technology, it would be almost impossible for non-US manufacturers to avoid using US components and parts, and therefore, the ITAR restriction was in effect a de facto exclusion of China from international space market. Some non-American companies such as Thales Alenia invented an idea of ITAR-Free satellite, which does not use any US-made component and is launched by Chinese launcher. The concept of ITAR-Free satellite was to compensate the higher production cost of satellite by cheaper Chinese launch. But gradually the cost of ITAR-Free satellite production has decreased (initially it was considered about $6 \%$ increase but currently it is estimated to $3-4 \%$ ), so that Thales Alenia kept producing ITAR-Free satellites for both Chinese and non-Chinese customers [26]. Although China imports ITAR-Free satellite for application (mostly communication) satellites, the ITAR gave China an incentive to invest in application technology to autonomously supply for growing demand for space-based infrastructure and services.

Following the White Paper of 2000, the State Council has published new White Paper in 2006 [27]. Basically, the objectives and principles are not so different, but there is a strong conviction that Chinese space program is on steady track, particularly with series of success in manned-space program. Also, this White Paper emphasizes civilian and peaceful nature of Chinese space program. It is considered as a response to 2006 American National Space Policy under Bush Administration which was issued a few months ago, and to emphasize the civilian and peaceful side of Chinese space policy. The US space policy document had a certain nuance that its space programs aims at protecting territory and national interest, and the US uses its technical superiority to reject any other country to disrupt American space activities [28].

This trend continued to appear in the most recent White Paper published in 2011 [29]. Although the contents that appears in the 2011 White Paper seems not too different from the previous two, the wording and context has changed slightly. On the one hand, China claims that its purposes of space policy are "to explore outer space and to enhance understanding of the Earth and the cosmos; to utilize outer space for peaceful purposes, promote human civilization and social progress, and to benefit the whole of mankind", but at the same time, the space programs also contributes "to meet 
the demands of economic development, scientific and technological development, national security and social progress; and to improve the scientific and cultural knowledge of the Chinese people, protect China's national rights and interests, and build up its national comprehensive strength”. This sentence will provide a general sense of feeling that the nationalistic aim and objective began to appear in the official document. One may interpret that this is a manifestation of Chinese intention to use space capability as its power in the region and the world. It is understandable that having space capability would contribute to the national security and interest, but this White Paper does not explicitly state how these programs can contribute to these policy objectives. Thus, the 2011 White Paper appears to be in a continuum of previous two despite the change of tone in its objectives.

Although the White Papers emphasized the civilian nature of Chinese space activities, there were significant developments in military space capability during this period. The President Hu Jingtao ordered the People's Liberation Army (PLA) to secure the access to space in 2004 as soon as he became the chairman of the Central Military Committee after the power struggle with his predecessor Jiang Zemin [30]. Along with the steep increase of the military budget for modernizing and expanding the military capability of PLA, Chinese defense authority invested in the satellite communications and navigation capabilities for catching-up with the American military capability driven by the concept of the "Revolution in Military Affairs". But it does not necessarily mean that China is challenging the supremacy in space, but to develop enough capability to defend its critical national interest such as Taiwan, and guarantee that it will not be threatened by other countries, particularly the United States [31].

\section{Leadership in Asia and Developing World}

China, on the one hand, represents itself as a leader of developing countries. This self-image gives certain aspect to pursue regional and global leadership in space policy. For example, Chinese government has initiated the "Declaration on International Cooperation in the Exploration and Use of Outer Space for the Benefit and in the Interest of All States, Taking into Particular Account the Needs of Developing Countries" [32]. China stresses that international space cooperation should be based on equality, mutual benefit, peaceful utilization and common development. This policy suggests that China would provide its technical know-how and space-based services for developing countries where major Western countries are not providing sufficient support. From China's perspective, developing countries are disadvantaged by their lack of industrial and technological capabilities, and they are not able to participate in international space community which is only made by advanced industrialized countries. Thus, China regards itself as a leader of developing countries to improve their technical capabilities for bringing them up to the level of international 
space community.

This approach can also be seen in Chinese endeavour to establish regional space cooperation organizations. In 1992, China, Pakistan and Thailand signed on MoU for establishing an international organization for space technology and application cooperation. This cooperation created an international space cooperation agency called AP-MCSTA (Asia Pacific Multilateral Cooperation in Space Technology and Applications) attracted many developing countries in Asia, including South Korea, Iran, Indonesia, Mongolia, Bangladesh and so on [33]. The objective of AP-MCSTA was to promote multilateral cooperation in space applications, but it was clear that China had the leading expertise. In fact, teaching and training of human resources were the main objectives of AP-MCSTA. It offers programs for remote sensing data analysis on environmental studies / protection, natural resource exploitation as well as in disaster monitoring and prevention. Those education and training, in fact, contribute to the promotion of capacity building for the Asia-Pacific Region. The organization has held 7 international conferences, attended mainly by engineers and scientists with some policy makers, for exchanging information and setting up workshops for various application programs. Among those workshops, Cooperation in Small Multi-Mission Satellites (SMMS) was the largest and most important one. SMMS was created by China, Iran, Republic of Korea, Mongolia, Pakistan, Thailand and Bangladesh for developing microsatellite for communications and remote sensing. China has been developing smallsat technology from early 1990s by sending students to the University of Surrey, and several university played incubator of such technologies brought back by those students. The SMMS project was, as a result, was functioning as a technology transfer mechanism from China to other members.

This Chinese leadership through AP-MCSTA has further developed by creating APSCO (Asia Pacific Space Cooperation Organization). In 2005, China, Bangladesh, Indonesia, Iran, Mongolia, Pakistan, Peru and Thailand signed the APSCO Convention and Turkey signed in 2006. The APSCO transformed AP-MCSTA into treaty-based cooperation framework with more explicit rules on program finance, data use and SMMS cooperation. The Convention of APSCO has some resemblance to the European Space Agency Convention, which suggests that the APSCO aims to be ESA-like international institution for the development of space technology [34]. However, it is undeniable that China has taken the leadership and forming the cooperation scheme without its competitors such as Japan or the United States. Also, the APSCO programs, if successful, would provide more launching opportunities for Chinese Long March which is discriminated by American ITAR.

The other aspect of exercising Chinese space leadership is the bilateral cooperation with 
resource-rich countries. China has been collaborating with Brazil on the Earth resources satellite program. Following the successful launch of the China-Brazil Earth Resources Satellite 2 (CBERS-2) in October 2003, the Chinese and Brazilian governments signed supplementary protocols on the joint research and manufacturing of follow-on satellites, and on cooperation in a data application system, maintaining the continuity of data of CBERS and expanding the application of such satellites' data region-wide and worldwide.

Also, China signed a commercial contract for a communications satellite with Nigeria, providing in-orbit delivery service to that country in 2004 and consequently, with Venezuela, providing in-orbit delivery service and associated ground application facilities in 2005. These two contracts were basically commercial contracts, but it suggests several important issues. First, China uses space technology as a bargaining tip for securing resource supply. As Space News reported, these countries "don't pay in cash but in raw materials, so in fact the satellite has no cost” [35]. So there is a mutual interest between China and these resource-rich countries to exchange their resources for satellite services. There are growing number of developing countries which demands for satellite communication capability for improving their national infrastructure. China, with its self-image of the leader of developing country, took advantage of its superiority in space technology, and offered space system, including launch service, with very cheap price. Second, these contracts suggest that Chinese industrial capability has achieved to the level of international commercial market. Increasing reliability of Chinese technology, together with its success of manned-space program, made Chinese space community confident that they can enter into commercial market.

\section{ASAT test}

Finally, we cannot avoid discussing about the Chinese experiment for shooting down its own satellite in 2007. This incident would tell us how China regards space, and how Chinese decision-making system works.

First of all, the Chinese decision to shoot down its aging weather satellite, FY-1, was taken by military authority without much consultation with space community as well as diplomatic corps [36]. This is why there was mixed messages from different Chinese authorities. The Ministry of Foreign Affairs, the "window for outside world", was not able to confirm or deny the fact that China took out its own satellite. It took twelve days of silence before a Chinese Foreign Ministry spokesman confirmed the test. In a brief statement, the spokesman said that the ASAT test "was not directed at any country and does not constitute a threat to any country”. But at the same time, the spokesman from the Ministry stressed that this was an act of peaceful use of space, since the action was not 
infringing with any international commitment, and reemphasized that China is committed to oppose weaponization of or any arms race in space [37]. The reaction indicates that the Ministry of Foreign Affairs was not informed, and the policy explanation was not well prepared.

Second, the reason and rationale for military force to exercise its capability for shooting down satellite was to challenge the US supremacy in space and prevent other countries to intervene Chinese action to protect its strategic interests. From China's perspective, the 2006 US National Space Policy can be seen as a clear statement that the United States will maintain the dominance in space, and in order to do so, the US would deny Chinese access to space. Together with the ITAR regulation which excludes China from international launch market, Chinese government considered that the American space policy was targeting China, and this space policy denies Chinese access to space, which was against the Chairman Hu Jintao's order. The strategy of "Anti-Access/Area-Denial" (A2AD) encouraged the PLA to demonstrate the capability to shoot down satellites which would enable other forces to penetrate the areas of Chinese concern [38]. However, it should be noted that China has planned and conducted three similar tests between 2004 and 2006 [39], the relationship between the ASAT test and the US National Space Policy was coincidental.

Third, Chinese space community, in contrast to military authority, was well aware of the impact of satellite destruction in orbit and subsequent spread of space debris. Since China is increasingly depending on space-based infrastructure and services, it was clearly recognized that the creation of debris would undermine their own space systems. This is the reason why Chinese government has fiercely promoted the protection of space environment and prohibition of damaging space objects. It seems contradictory for China to demand such international regulations, but it is understandable if we take into account the two different communities in China.

In fact, China has actively participated in activities organized by the Inter-Agency Space Debris Coordination Committee, started the Space Debris Action Plan, and strengthened international exchanges and cooperation in the field of space debris research. It also proposed together with Russia for establishing a guideline for protection of space environment in 2007. China also strongly promotes prohibition of "weaponization" of space in PAROS (Prevention of an Arms Race in Outer Space) under CD (Conference on Disarmament). Together with Russia, China placed the draft "Treaty on Prevention of the Placement of Weapons in Outer Space and of the Threat or Use of Force against Outer Space Objects” or PPWT [40]. Although this draft treaty only prohibits the placement of weapon in earth orbit and excludes the use of ground-based weapon to attack space objects, the Chinese and Russian proposal can be considered as an attempt to demonstrate Chinese 
intention to be active in the process of setting up international coordination for space sustainability. However, the United States is strongly against for setting up any legal framework to restrict American activity in space during Bush Administration and even in the Obama Administration, the United States and other spacefaring nations disagree with the Russo-Chinese proposal for reasons that this treaty does not prevent the attack from the ground-based missile or jamming.

\section{Chinese approach to 'space race' in Asia}

From the perspective of this article, this brief analysis on Chinese space policy in this century suggests that the space race is not happening in Asia, at least, in two facets. For the first facet, competition of prestige or soft power, China aims higher than what Japan is aiming for, and its objective seems to be catching up with what other two space powers, the United States and the former Soviet Union achieved. In this facet, China does not pay much attention to what Japan does.

Again, for the second facet, competition of military capability or hard power, China seems to target the US military capabilities in space. The development of its own navigation satellite system, Beidou or Compass, is equivalent to the US GPS, and aims to avoid dependence on it. The A2AD strategy and modernization of Chinese military capability were the responses to compete, or at least, to protect Chinese vital interest in Asia. The ASAT tests also proved that the Chinese prime concern is the US capabilities in space, not Japanese one. Of course, having space capability comparable to the US one means that Chinese space hard power capability is far more superior than the Japanese one. However, it is not space race between Japan and China.

Thus, the third facet, competition of international services or public goods, is where China is competing against Japan. In 2009, a delegation of APSCO secretariat visited JAXA as a part of its global tour and demonstrated its achievement. Since 2010, APSCO representative attends to APRSAF meetings and outlined the activities of APSCO. This rapprochement seems to ease the rivalry between these two organizations, but up until now there is no discussion over institutional cooperation or working together in overlapping activities. It seems that China wants to maintain its leadership of APSCO as much as Japan wants it for APRSAF.

\section{Summary: It's not Space Race, but competition of the leadership}

This article discussed the possibility of space race in Asia, particularly between Japan and China. It defined that there are three facets of space race, namely the competition of prestige or soft power as 
the first facet, the competition of military capability or hard power as the second, and the competition of international services or public goods as the third facet.

It is misleading that there is a competition between Japan and China for seeking international prestige or soft power by pursuing manned-space capability. China has been successfully continuing its manned-space program, but Japan is reducing its commitment in manned-space capability. The Space Policy Commission has gave the lowest priority for the manned-space programs in the budget plan for FY2013 [41]. The priorities as well as the policy objectives of Japan and China has quite different, which means that these two countries are not competing in the first facet of the space race one against another.

It is also misleading that there is a competition between Japan and China for improving military capability in space. It is true that Japan has launched Information Gathering Satellites (IGS), and China is developing application technologies which might be useful for military space system. However, the rationale for Japan and China to develop its security related capabilities are quite different. They are not looking at and competing to each other. Rather, Japan has developed its capability to respond to the rising threat of North Korea, and China is aiming to develop its A2AD capabilities. Although the tension between Japan and China is intensifying, both countries are not gearing up their speed of development for military space capabilities. From these aspects, it would be difficult to assume that Japan and China are in space race on the second facet, competition of military capability or hard power. Also we have to be aware that space is only a tool for military activities. No country in the world is using space for battle ground. It is prohibited to place weapons of mass destruction in the orbit, and many countries accept the idea of avoiding "weaponization" of space (in fact, China is the sponsor of the treaty to ban space weaponization through PPWT in PAROS).

Also, we have to take a note that the ASAT test in 2007 made everyone including China to be aware of the danger of space battle. The destruction of satellite would create large amount of debris, which would affect not only the enemies but also its own satellite in orbit. Whatever the reason for shooting down satellites, the consequence of the action would be enormous and unfavourable to any spacefaring nations. This is why China has conducted another ASAT test in 2010 in a very low altitude which avoided creating debris that affect space assets including Chinese one. After all, any space activities are determined by the fairest law, which is the Law of physics. The Law of physics does not discriminate civilian and military spacecrafts, enemy and friends, and good and bad intentions. Thus, it would be too straightforward to determine that the Chinese ASAT would invoke military competition in space. 
Some might argue that the recent dispute over Senkaku/Diaoyu islands may spur the tension between Japan and China, which eventually would impact on the Chinese military space strategy, but the "space race" or "space war" between Japan and China will be unlikely, because the degree to which Japan depends on the space assets for its territorial defence is very limited. As discussed above, Japanese military has long been refrained from investing, developing, owning and operating space systems. Japanese Missile Defence system is constituted by entirely ground-based systems, and the satellite early warning signals are received from US satellites. Thus, if China has an intention to disable Japanese military system, it has to attack ground-based system instead of space-based system. It would be difficult to assume that Japan and China are competing in the second facet of space race

However, there is a competition between Japan and China for leadership. The rivalry between APRSAF and APSCO is stimulating both Japan and China for using these organizations as a vehicle for exercising their leadership. China and Japan keenly compete in the regional leadership by assisting technical capacity building to developing countries and providing services through their space assets. Both Japan and China are playing the same game with the same rules to figure out who is taking the leadership in Asia. Thus, it can be said that there is a space race between Japan and China, but it is more about the race to become the space leader in this region. Their aims are not to be on top of the rival in space, but to utilize their space capability for diplomatic activities. There is a space race between Japan and China, but it's only limited to the competition of the leadership.

\section{$\underline{\text { References }}$}

[1] James Clay Moltz, Asia's Space Race: National Motivations, Regional Rivalries, and International Risks, Columbia University Press, 2011

[2] Bob Yirka, "National Security Expert Warns of Asian Space Race", Phys.org, December 8 , 2011. http://phys.org/news/2011-12-national-expert-asian-space.html

[3] Peter Ford, "What's Behind Asia's Moon Race?", The Christian Science Monitor, October 25, 2007. http://www.csmonitor.com/2007/1025/p06s01-woap.html

[4] Denise Chow, "Asian Space Race Is Heating Up, US Policy Expert Warns", SPACE.com, 
http://www.space.com/13850-asia-space-race-china-india-competition.html

[5] Kyle Niemeyer, "Asia's Space Race Could Turn into an Arms Race", ARS Technica,

Dec 12011.

http://arstechnica.com/science/2011/12/asias-space-race-could-turn-into-arms-rac e/

[6] For example, see Saadia M. Pekkanen and Paul Kallender-Umezu, In Defense of Japan: From the Market to the Military in Space Policy, Stanford University Press, 2010. See also the review of this book by Kazuto Suzuki, Book Review: In Defense of Japan: From the Market to the Military in Space Policy, Space Policy, Volume 27, Issue 3, August 2011, Pages 186-187.

[7] For example, see Citizen's Charter of Indian Department of Space (http://dos.gov.in/citizencharter.htm). It states "The Department of Space has the primary objective of promoting development and application of space science and technology to assist in all-round development of the nation".

[8] The Space Foundation, The Space Report 2012. Colorado Springs: The Space Foundation, 2012. The Chinese civil space budget figure is an estimate, since there is no reliable official figure.

[9] The Indian interest on space security is concerned as a reaction to the Chinese ASAT test in 2007. Though this is a reaction in the context of regional security, India did not take it as regional but global affairs. See Bharath Gopalaswamy, "Space Security", in Ashley J. Tellis and Sean Mirski (eds.) Crux of Asia: China, India and the Emerging Global Order, Carnegie Endowment for International Peace, 2013.

[10] Space Race, The Oxford Essential Dictionary of the U.S. Military, Oxford University Press, 2004.

[11] Kazuto Suzuki, "Space and Security: Japanese Perspective" in Penser les Ailes françaises, No.16, 2008, pp.57-68

[12] Tsugio Ishikawa, Special Commission on Promoting Science and Technology, The 
61st Session of The House of Representatives, May 8, 1969.

[13] Kazuto Suzuki, "Basic Law for Space Activities: A New Space Policy for Japan for the 21st Century" in Kai-Uwe Schrogl, Charlotte Mathieu, Nicolas Peter (eds.), Yearbook on Space Policy 2006/2007, Springer Wien New York/European Space Policy Institute ，2008, pp.225-238

[14] Takeshi Sunohara, Tanjo Kokusan Supai Eisei (The Birth of National Spy Satellites). Nikkei BP Publishers, 2005

[15] Study Group on National Space Strategy (Kokka Ucyu Senryaku Ritsuan Konwakai), Report of the Study Group: For the Establishment of New Space Development and Utilization Institutions (Houkokusyo: Aratana Ucyuu Kaihatsu Riyou Seido no Kouchiku ni Mukete), October 2005.

[16] Setsuko Aoki, “Current Status and Recent Developments in Japan's National Space Law and Its Relevance to Pacific Rim: Space Law and Activities", Journal of Space Law, 36(2), 2009, pp 335-364

[17] Bill Emmot, How the Power Struggle Between China, India, and Japan Will Shape Our Next Decade, Hartcourt, 2008, especially p.13.

[18] Saadia M. Pekkanen, Picking Winners? From Technology Catch-up to the Space Race in Japan, Stanford University Press, 2003.

[19] Takeo Kawamura, Regular Press Briefing, Prime Minister's Office, 28 September, 2008.

[20] Interview with JAXA official, October 11, 2005 at Kitakyusyu, Fukuoka, Japan.

[21] For the history of APRSAF See http://www.aprsaf.org/about/

[22] Koichiro Genba, Speech of the Foreign Minister: Japan's Efforts in the Global Agenda: Implementing "Full Cast Diplomacy" and Expanding the Frontiers of International Cooperation, National Graduate Institute for Policy Studies (GRIPS), February 28, 2012 
[23] The Information Office of China's State Council, China's Space Activities: White Paper, 2010. http://www.china.org.cn/e-white/8/index.htm

[24] Gregory Kulacki and Jeffrey G. Lewis, A Place for One's Mat:China's Space Program, 1956-2003, American Academy of Arts and Sciences, 2009

[25] Roger Handberg and Zhen Li, Chinese Space Policy: A Study in Domestic and International Politics, Routledge, 2012.

[26] Federal Aviation Administration, Semi-Annual Launch Report: Special Report "ITAR-Free" Satellites and Their Impact on the U.S. Launch Industry", October 2010.

http://www.faa.gov/about/office_org/headquarters_offices/ast/media/2010-2\%20Se mi-Annual\%20Layout\%20Final.pdf

[27] The Information Office of China's State Council, China's Space Activities in 2006, 2006. http://www.fas.org/spp/guide/china/wp2006.pdf

[28] US National Space Policy, August 31, 2006. http://www.whitehouse.gov/sites/default/files/microsites/ostp/national-space-polic y-2006.pdf

[29] The Information Office of China's State Council, China's Space Activities in 2011, 2011. http://news.xinhuanet.com/english/china/2011-12/29/c_131333479.htm

[30] Dean Cheng, "China's Military Role in Space", Strategic Studies Quarterly, Spring 2012, pp. 55-77.

[31] See, for example, Joan Johnson-Freese, China's Space Ambitions, IFRI Proliferation Paper, Summer 2007.

[32] "Declaration on International Cooperation in the Exploration and Use of Outer Space for the Benefit and in the Interest of All States, Taking into Particular Account the Needs of Developing Countries", A/RES/51/122, UN General Assembly, 13 December 1996 
[33] For the history of AP-MCSTA and APSCO see http://www.apsco.int/history.aspx

[34] Convention of APSCO can be found at http://www.apsco.int/UploadFile/2009924/F1TKF8A2009924.pdf

[35] Peter B. de Selding, "Chinese Hardware, Financing Changing Satcom Landscape", Space News, January 18, 2013

[36] Interview with Chinese Ministry of Foreign Affairs official, May 19, 2011.

[37] Bonnie Glaser, Old and New Challenges: ASAT Test, Taiwan and Trade, Comparative Connections, CSIS, April 2007.

[38] Shirley Kan, CSR Report for Congress, "China's Anti-Satellite Weapons Test", CRS-4, April 23, 2007

[39] Craig Covault, "Chinese Test Anti-Satellite Weapon" Aviation Week \& Space Technology (online), Jan. 17, 2007

[40] The text of PPWT can be found at http://www.cfr.org/space/treaty-prevention-placement-weapons-outer-space-threa t-use-force-against-outer-space-objects-ppwt/p26678

[41] Space Policy Commission, Follow-up of Strategic Budget Distribution Guideline for Space Development and Utilization for FY2013, January 24, 2013. http://www8.cao.go.jp/space/comittee/dai11/siryou1.pdf 